\title{
Managing university degree programmes acceditation in the era of economic recession in Nigeria
}

\author{
Ahaotu Godwin Ndubuisi ${ }^{1}$ \\ Federal University of Agriculture Makurdi, Nigeria. \\ Department of Educational Foundations and General Studies. \\ E-mail: godwinahaotu@gmail.com \\ Ogunode Niyi Jacob ${ }^{2}$ \\ Federal University Wukari, Nigeria \\ E-mail: Ogunodejacob@gmail.com
}

\begin{abstract}
Annotation. The economic recession experienced in Nigeria between 2015/2017 was a great concern to the management of the university system especially with shortfall in the prices of oil and gas in the global market. It would not be an understatement to say that, Nigeria university degree programmes accreditation would suffer because funding of these programmes comes from oil and gas revenue due to Nigeria mono-economy. It is evidently glaring that managing programmes accreditation during this dispensation would be affected in no small measure due to the economic recession. In view of the above, this paper would examine the following: the concept of university management, university programmes, programmes accreditation, objectives of accreditation, accreditation instrument, criteria for programme accreditation, challenges of accreditation, sources of funding university degree programmes, economic recession and its effect on university management, recommendations and conclusion.
\end{abstract}

Key words: Accreditation, Academic Brief, Management, University.

\section{INTRODUCTION}

Koontz, H. and O'Donnell, C., (2013), defined University Management as the leadership capacity required by the management of any university for ensuring success and survival of that university. The achievement of the vision, mission and objectives of the university depends on management. Koontz and O'Donnell (2013) further state that university management is the optimal utilization of the resources available for goal attainment. Koontz and Weirich, H (1986) opined that university management is the process of laying out plans and consciously implementing the plans in order to achieve a successful institution. By this definition, university management involves planning, organizing, staffing, coordinating, programming, implementing, evaluating, reprogramming, re-implementing and re-evaluating the entire system to achieve the purpose of its establishment vis-à-vis the mission, vision and objectives.

\subsection{UNIVERSITY PROGRAMMES}

\section{MAIN PART}

Viasceanu, Grumaberg and parica (2007) note that Programmes within the content of the Academic Brief of the individual university subject to accreditation by the accrediting bodies and are certified as such, are referred to as the university programmes. Further clarification by Njenga (2008) is that an Academic Brief is like the Holy Bible of any institution because it provides coherent guide for progression and development of the institution. It takes into account the phases of the institution's development and the accompanying resources required. Ignatius, I.V (2012) states that the preparation of an Academic Brief for any university is based on the following premise:Long term objectives, academic structure, administrative structure, students population projection, staff projections, expected research areas, community service programmes, rate of growth. An academic brief is usually documented in two volumes. Volume one contains ten chapters with the appendices while Volume Two of the academic brief contains the course synopses for the academic programmes offered by the institution.

\subsection{IMPORTANCE OF ACADEMIC BRIEF}

Olagbemi (2012), says that the relevance of Academic Brief in any tertiary institution cannot be over emphasized because, not only that it dwells richly on academic activities, it also touched the areas of due diligence with regards to physical development of the concerned institution, the academic pattern, organizational structure as well as the anticipated progression and projection of the growth and development pattern. Academic Brief is a guide for the academic and physical growth and development of the institution. Specification of the standards for each physical structure to be provided in the institution for office, academic activities are all clearly specified in the Academic Brief. Due diligence in obeying the Academic Brief would provide insight to the Management on areas of seeming challenges like, revenue, students admission quota ( merit, catchment and education least disadvantaged areas), science/arts ratio, growth rate and carrying capacity.

\subsection{DEFINITION OF ACCREDITATION}

The accreditation of degree and other academic programmes by the National Universities Commission means a system for recognizing educational institutions (Universities and programmes offered in these institutions) for a level of performance, integrity and quality which entitles them to the confidence of the educational community, the public they serve and employers of labour. (NUC, 2011). 


\subsection{OBJECTIVES OF ACCREDITATION OF DEGREE PROGRAMMES IN THE UNIVERSITY}

The objectives of accreditation of academic programmes in Nigerian Universities are to:

Ensure that at least the provisions of the Minimum Academic Standards document are attained, maintained and enhanced; Assure employers and other members of the community that Nigerian graduates of all academic programmes have attained an acceptable level of competence in their areas of specialization; and Certify to the international community that the programmes offered in Nigerian Universities are of high standards and their graduates are adequate for employment and for further studies.

According to Oladosu, A.G.A.S (2012), in CODAPNU book project, (2012), he observes that the importance of providing and maintaining a continuous mechanism with a view to raising academic standards, in addition to improving minimum standards was the rationale for the establishment of accreditation in higher institutions. He further states that this was seen to be of great value to stakeholders of higher institutions. Students and parents are assured of the quality of instructions in accredited programmes. The employment of graduates from the institutions whose programmes are accredited is beneficial for these graduates and shows that such graduates are capable of contributing effectively and efficiently to the World at work.

The Committee of Directors of Academic Planning of Nigerian Universities (CODAPNU 2012), also stated that accreditation is an external quality assurance exercise conducted to ensure that a given educational institution operates within the ambit of established guidelines laid down by an officially recognized accreditation agency. Hornby (2001) opines that it could also signify the official approval granted or certificate awarded by an accrediting body to an accredited institution at the end of a successful externally quality assurance exercise. An external quality assurance exercise which is similar to accreditation is a resource verification/assessment visit. Such a visit is traditionally made to new Academic programmes, Academic Departments or faculties before they are officially granted approval to take off.

A panel of experts from related academic areas of specialization consisting of administrators, experts in library sciences, and representatives of the National Universities Commission, visits the relevant unit to ensure that quality is maintained and to determine the extent of the unit's readiness. Approval to take off is strictly based on a satisfactory assessment of the quality of human and physical facilities, including staff/student ratio, academic and non-academic staff qualifications, philosophy and objectives of curriculum, curriculum content, library holdings, currency of books and journals, infrastructure and source of funding. The panel reports back to the NUC which communicates the outcome to the concerned institution.

\subsection{JUSTIFICATION AND LEGAL BASIS FOR ACCREDITATION OF PROGRAMMES}

The national Policy on Education (NPE 2004) underscores the significance of education by saying it is "an instrument par excellence" for effecting national development. With particular reference to tertiary institutions, the policy document statement stipulates among other things, that Nigerian universities shall "intensify and diversify their programmes for the development of high-level manpower within the context of the needs of the country." It also adds that the universities shall make the content of professional courses to reflect our national requirements" (NPE 2004).

It is important to note that the legal basis for accreditation of academic programmes in Nigeria is derived from section 10, Act No. 16 of 1985. This was incorporated as section 4 (m) of the NUC amended Act No. 49 of 1988, which empowers the Commission to "lay down Minimum Academic Standards for all universities in the country and to accredit their degrees and other academic awards" (Okojie 2008).

On the strength of the above Act, the NUC developed a set of Minimum Academic Standards (MAS) to guide Nigerian universities in the development, implementation and evaluation of their curricula. The MAS was reviewed by the NUC in 2004 and resulted in the development of Benchmarks Minimum Academic Standards (BMAS) (Okojie, 2008). There is no doubt that the BMAS aims at achieving some general and specific objectives which are the focus of the next point of discussion.

\subsection{DEGREE PROGRAMMES ACCREDITATION INSTRUMENT}

The National Universities Commission developed the Minimum Academic Standards in 1989. By 1990, the Commission had worked out the procedure for the accreditation exercise with the production of the following materials (NUC, 2012).

Self-Study Forms (SSF): The Self-Study form is divided into sections: Sections 'A' and 'B'. Section 'A' solicits general information about the university and requires the Vice-Chancellor or designated officer of the university visited to provide the information. The section ' $\mathrm{B}$ ' solicits information about the programmes to be accredited and requires the Head of the Department of the programmes to be accredited to provide information.

Manual of Accreditation Procedure for Academic Programmes in Nigerian universities. This document provides the detailed information on the objectives, processes and specimen of the other forms that have been completed by the universities and panel members for each of the programmes. 
Programme Evaluation Form (PEF). This form is to be completed by each panel member. The form provides scoring columns and columns for relevant comments.

Accreditation panel Report for each of the programmes being accredited. The summary of scores and accreditation status are entered into the space provided in the form.

Minimum Academic Standards Document. The Minimum academic Standards document contains the minimum course contents in each degree programme, minimum physical facilities; minimum laboratory space; as well as library and the staff/student ratio.

\subsection{CRITERIA FOR PROGRAMMES ACCREDITATION}

Okebukola (2010) highlighted the under listed factors as the essential ingredients required for programme accreditation in the Nigerian university system.

(a)Philosophy and Objectives of the Programme to be Accredited

There shall be evidence that the programme to be accredited has clearly defined philosophy and objectives. Panel Members will judge the quality of the programmes in terms of the efforts being made by the University to achieve the stated philosophy and objectives of the programme. The minimum expected will be similar to those laid down in the NUC approved Minimum Academic Standards (MACS) for the programme.

\section{(b) Curriculum}

The curriculum of the programme to be accredited should be adequate to prepare practitioners at an appropriate level in the particular field. It should include adequate theoretical knowledge and skills to fulfill the requirements for specific job objectives, and to equip the graduates with adequate communication skills (written and oral) and a sound knowledge of the social, political and economic environment in which the graduate shall live, work and make useful contributions as citizens.

The Panel will require evidence that the curriculum of the programme to be accredited meets the above requirements. The minimum expected will be those prescribed in the NUC, Minimum Academic Standard (MACS). In addition, panel members will ascertain that the general atmosphere in the University indicates that the curriculum requirements were being met. The correctness of the above statement will be defended before the Accrediting Panel members

with documentary evidence of individual course content, textbooks for the course, students' work, lecture notes and descriptive materials and annual external examiners' reports of final examinations for three years preceding the visit.

(c)Teaching Staff Quantity and Quality

The Teaching staff adequacy in numbers, competence and the standard of instruction that it maintains in all subject areas that provide instruction to the students will be taken into consideration. Generally, the teaching staff determines the adequacy of the programme as instructional goal and objectives are achieved only to the level of competence and vision of the teaching staff. The overall competence of the teaching staff may be judged by such factors as:

The level of academic/profession training; their cognate teaching experience and professional work; the diversity of their background; the extent of which they further their own education in relevant programmes that ate offered in the College/School/Faculty/Department the degree of their participation in professional association/societies; the existence of staff development programme for the improvement of the teaching force and curriculum; good working conditions to attract and retain staff of high quality, for example, living accommodation, etc; a reasonable teaching load in hours per week, which should not be less than the stipulations in the Minimum Academic Standards (MACS).

(d) Students Admission, Retention and Graduation

The University should have policies on admission, retention, withdrawals, expulsion and graduation of students clearly spelt out in its annual Calendar of students' handbook. There shall be evidence that these policies are properly explained and widely publicized for the information of all students either seeking admission or already enrolled in the University. For admission into any of the degree programmes, the minimum qualification expected shall be in line with existing National Policy on Admission to Nigerian Universities. For graduation, candidates should have fulfilled the minimum requirements for the award of a degree which include a satisfactory completion of a minimum practical, core/compulsory and elective courses stipulated in MACS.

\section{(e) Standards of Degree Examination}

In general, the University should have rules and regulations governing degree examinations and awards. These rules and regulations should be carefully explained to students on enrolment and widely publicized. The standard of examination leading to the award of degree shall appropriate for the level of programme and adequate coverage of the syllabus. The sources of information to Panel members, on this matter, will include: degree final examinations past question papers, homework problems, coursework, projects and external examiners/moderators' reports for the three years preceding the visit. Also to be made available to members is a report of students' supervised industrial experience schemes, teaching practice where applicable, etc.

(f) Financial Support 
There should be adequate financial support to the University and to the department where the programme to be accredited is offered as a measure of dedication to the philosophy and objectives of the programme, and as predictors of continuing quality in education and evidence of programme stability.

(g) Physical Facilities

There shall be adequate physical facilities classrooms, laboratories, studios, workshops and tolls, instruments machines, equipment and provision for updating the physical facilities and for expandable supplies to give students proper learning experiences essential to achieving their educational philosophy and objectives.

The accreditation Panel will require evidence that adequate physical facilities exist and that they were being used to educate the student in various aspects of skills or in the techniques of applied design, construction, operation and production processes in technology based programmes respectively.

\section{(h) Administration of Department}

The effect on productivity of sound administrative policy and effective leadership cannot be over-emphasized. A capable staff can be more effective if he performs his function in an atmosphere of good relationship with the administration. Administrators should perform their leadership role with mutual concern with policies that affect teaching and support staff and students of the department. The roles of the administrator in the department include selection and supervision of students; teaching and other staff members, the operation of the facilities for staff and students, conduct of examinations and interpretation of the department to members of the profession and to the public. There should be evidence to Panel members that in performing these functions, the administrator seeks advice from the teaching staff, staff committees and other staff where necessary.

(i)Employers' Rating of Graduates

As evidence of meeting the philosophy and objectives of the programme, the Accreditation Panel will require a displayed employers' satisfaction that graduates of the programme are performing well at their various levels of employment. The evidence should be the result of a survey of the graduates' employers to ascertain that there is a rating of satisfactory performance of the graduates in their chosen fields. Where a University has not graduated any student from the programme to be accredited, employers' rating of the students' course practical work/projects in the programme may be assessed by Panel members in lieu of employers' rating of graduates. (Alden and Lin 2004; Okebukola 2008; Salmi 2009; Okebukola 2010)

\subsection{FUNDING OF UNIVERSITY PROGRAMMES/ ACCREDITATION}

There are two obvious sources of funding the university system in Nigeria. These are the conventional sources and the alternative sources. Conventional sources of funding the universities in Nigeria are the following according to Tyokyaa and Odey (2017) :

Government Subventions (Grants): Government grants and subventions constitute a very substantial proportion of the finance that is available for use by the universities in Nigeria. According to Akangbou (1987), these grants could be capital or recurrent grants. The former (capital), when paid to universities, is meant for the erection or construction of new buildings, carrying out of major repairs of old structures and the purchase of hardware, school equipment such as laboratory and library facilities etc.

(a)Tuition Fee/Levies:

When students attend school or classes in the universities, they are likely to pay for the lectures they receive from teaching. When such payments are made, we say that tuition fee are paid by students. Usually tuition fee is not the only payment made by students; they may have to pay levies for such purposes as examinations, laboratory use, development, hostel accommodation, hall maintenance fee, admission screening fee etc

(b) Government Education Tax Fund (ETF):

The Education tax Fund was established through the Education Tax Decree Number7 of 1993 which compelled companies operating in Nigeria, which have up to one hundred (100) employees on their pay roll to contribute $2 \%$ of their pre-tax earnings in any one year to the Education Tax Fund (ETF) for the funding of education. The ETF has so far made its presence felt in many universities and other tertiary institutions in the country through the construction and or rehabilitation of new classroom blocks, hostel, staff office complexes, laboratories etc. Alternative sources include;

(c) Donations and Endowment Funds:

Another source of financing the universities is through donations and establishment of endowment funds. These are made by corporate organizations especially Multi-national companies, communities and individuals who are eager to contribute to the upliftment of higher education in the states or the country. Most of these donations are essentially free willing gifts in cash or in kind to universities. Such grants have been quite small. In the past, substantial (foreign) grants were received from organizations like the United Nations Educational Scientific and Cultural Organization (UNESCO), the United Nations Development Programme (UNDP), the Ford Foundation, the Rock feller Foundation, the Carnegie Foundation, The German Academic Exchange services(DAD), Canadian International development Association (CIDA),etc. These grants were mainly geared towards adding programmes in the universities, especially postgraduate studies, staff development and programme accreditation facilitation. Unfortunately, these grants actually declined when Nigeria's oil 
wealth gave the impression that such aids were no longer necessary. In recent time, some universities have been making frantic effort in launching endowment appeal funds but unfortunately, very little have been realized from the effort.

(d) Internally Generated Revenue:

In response to the government mandate that each university must generate at least $10 \%$ of its total revenue, each university has now embraced vigorous, commercial ventures and linkages with the productive sector. Most universities are now involved with running commercial ventures of different kinds, ranging from hotel services, primary and secondary schools, publishing, consultancies, supermarkets, bookshops, sales and marketing, including petrol stations.

4.0 Challenges of Managing Institutional Programme Accreditation in the Era of Recession

Challenges are factors, circumstances or situations that tend to test an individual's ability to achieve his or her objectives. In the context of programme accreditation, the ultimate goal of the exercise is to ensure that all the programmes and activities of a university are of international standards and quality. Incidentally, a number of factors constitute the challenges to the actualization of this ultimate goal. These factors include the following:

\section{(a) Funding:}

This is probably the thorniest and most perennial of the various challenges of programme accreditation. This is because all other indices of this exercise are closely interwoven with money. For instance, funds are required to employ academic and non-academic staff. Funds are basic to ensure quality infrastructure. They are essential to ensure the standard of the academic content of an institution. No university can do without money in its bid to ensure a peaceful, safe and conducive academic environment. To address the challenge of funding, some universities turn to foreign aid and donor countries to augment their finances especially during institutional and programmes accreditation to escape denial of accreditation. Under funding remains a very big huddle for degree programmes accreditation because of the enormous demands associated with the exercise. There is no gain saying that the prevailing economic recession currently been experienced in the country will in no small measure dampen the entire essence of programme accreditation hence the Federal government of Nigeria remains a mono-economy.

Kapur and Growly (2008) are of the opinion that to compete with technologically advanced nations, African universities need international donors. But, the duo realized the danger inherent in relying heavily on foreign aid because; donor countries may impose donor principles and culture on educational system of the benefiting countries.

Tyokyaa, and Odeh, (2017) Monograph on administration of tertiary institutions in Nigeria stated that the greatest problems facing higher education in Nigeria is that of gross under-funding. The problem of under-funding and over reliance on government remains a major confrontation for the university administrators in Nigeria. Consequent upon the financial constraints facing the universities, the infrastructures are dilapidated and inadequate, students face difficult conditions for learning in terms of overcrowded classes and hostels, inadequate library and laboratory facilities, inadequate water supply, irregular electricity supply, dehumanizing living conditions by both staff and students alike. In many public universities in Nigeria, students are found standing outside the classrooms receiving lectures, as their population has outstripped the classroom spaces that are available.

(b) Another major challenge of Institutional Programme Accreditation is ineffective administration of the universities. The so called political god fatherism has led to appointment of persons that are administrative misfits in the management of the universities, this has led to universities crawling instead of growing. Some of the university administrators embezzle funds that are meant for programme accreditation, university programme expansion and using university funds to win simparthy and support of Academic Staff Union of Universities (ASUU) executive as fighting just courses.

\subsection{The Term Economic Recession and Its Effect on Accreditation}

Merriam-Webster Online Dictionary. Retrieved August 8, 2017 and Encarta World English Dictionary,North American Edition defined recession as when the economy declines significantly for at least six months. That means there's a drop in the following five economic indicators: real GDP, income, employment, manufacturing and retail sales. A recession has many attributes that can occur simultaneously and includes declines in component measures of economic activity (GDP) such as consumption, investment, government spending, and net export activity. These summary measures reflect underlying drivers such as employment levels and skills, household savings rates, corporate investment decisions, interest rates, demographics, and government.

Problems of Economic Recession and its associated effects on institutional programme accreditation.

Douglas Cohen, (2008) identified the following problems as the aftermath of recession in any economy. These problems are as follow:

(a) Falling Output. Less will be produced leading to lower real GDP and lower average incomes. Wages tend to rise much more slowly or not at all.

(b) Unemployment. The biggest problem of a recession is a rise in cyclical unemployment. Because firms produce less, they demand fewer workers leading to a rise in unemployment.

(c) Higher Government Borrowing. In a recession, government finances tend to deteriorate. People pay less tax because of higher unemployment and they need to spend more on unemployment benefits. This deterioration in government finances 
can cause markets to be worried about levels of government borrowing leading to higher interest rate costs. This rise in bond yields may put pressure on governments to reduce budget deficits through spending cuts and tax rises. This can make recession worse and more difficult to get out of.

(d) Devaluation in exchange rate. Currencies tend to devalue in a recession because, in a recession, people expect lower interest rates and so there is less demand for the currency. However, if there is a global recession and all countries are affected, this may not occur.

(e) Hysteresis. This is the argument that a rise in temporary (cyclical) unemployment can translate into higher structural (long-term) unemployment. If someone has been unemployed for a year during a recession, they may become less employable (e.g. lose on the job training, e.t.c)

(f) Falling asset prices. In a recession, there is less demand for buying fixed assets such as housing. Falling house prices can aggravate the fall in consumer spending and also increase bank $(\mathrm{g})$ losses. This fall in asset prices is particularly a feature of a balance sheet recession.

Falling share prices. Lower profits lead to lower levels of share prices.

(i) Social problems related to rising unemployment, e.g. higher rates of social exclusion.

(j) Increased inequality. A recession tends to aggravate income inequality and relative poverty. In particular, unemployment (relying on unemployment benefits) is one of the largest causes of relative poverty.

(k) Rise in Protectionism. In response to a global downturn, countries are often encouraged to respond with protectionist measures (e.g. raising import duties). This leads to retaliation and a general decline in trade which has adverse effects.

\section{CONCLUSION}

Managing degree programme accreditation in the era of economic recession in Nigeria is no mean tasks considering the associated effect of recession on the nation's economy. This paper has been able to examine issues in managing institutional programme accreditation from the point of view of the concept of institutional management, institutional programme, programme accreditation, objectives of programme accreditation, Programme accreditation instrument, criteria for programme accreditation, challenges of programme accreditation and economic recession and its associated effects on institutional programmes.

The paper examined the sources of funds available to universities and the usability of such funds. The paper recognized that economic recession is a serious backslides and as such, managing institutional programme accreditation is not an easy exercise given the volume of fund required and government's lean purse measure presently. The paper however recommends that universities should as a matter of urgency try and intensify research effort and commercialize the dividend of such effort as an alternative fund raising sources of revenue, suggestion is also made

For programme expansion especially at the post graduate level will assist in income generation. These areas are perceived to be the building blocks for revenue generation and alternative sources of income for sustainable growth and enduring management of degree programme accreditation in the era of economic recession in Nigerian universities.

\section{References}

\# Alden, J. and Lin, G. (2004). Benchmarking the Characteristics of a World Class Developing an International Strategy at University Level, London: Leads Books

University:

Publishers.

* Akangbou, S.D. (1987). The Economics of education: An introduction, Ibadan: Shaneson

Federal Republic of Nigeria (FRN, 2004). National Policy on Education, Lagos: NERDC

* Hornby, A.S., ed.(2001). The Oxford Advanced Learner's Dictionary of Current English, Oxford University Press.

* Ignatius, I.V. (2012). Practical Guide on Academic Planning in Nigerian Universities: A of Academic Planning tools: Ibadan, Atlantis Books.

* Kapur, D. and Growly,M. (2008). Beyond the ABCs: Higher Education and developing Centre for Global Development Working Paper No. 139.

* Koontz, H and Weirich, H. (1989). Higher Education Management $9^{\text {th }}$ Edition: McGraw-Hill Book Company.

* Meriam-Webster Online Dictionary. Retrieved August 8, 2017.

* National Universities Commission and Association of African Universities (2010). Draft for Institutional Self-Accreditation, Abuja: NUC/AAU.

* Njenga, B.K., Bissoonnajuth, R., and Diarra, M., eds.(2008). Developing an African Higher Education Quality Rating Mechanism, Addis Ababa: African Union Commission: Department of Human Resources, Science and Technology.

\# Okebukola, P. A. O.(2008). World-Wide University Ranking: For whom, by whom? $24^{\text {th }}$ Lecture, University of Ilorin, $21^{\text {st }}$, October.

* Okebukola, P.A.O (2010). World-Class Status for Nigerian Universities: Goals, Pathways, in Okojie, J, Oloyede, Is-haq and Obayan, P.A.I (2010). 50 years of
C.I Ltd.

Press.

Oxford:

Compendium

Countries.

Singapore, New York:

Instrument

Convocation

Challenges and university 
Education in Nigeria: Evolution, Achievements and future Directions,

Universities Commission

Oladosu, A.G.A.S. (2012). Quality Assurance in the University System. Ibadan: Atlantis Books.

* Olagbemi, Osasona (2012). Tools for Academic planning. Ibadan: Atlantis Books.

* Salmi, J.(2009). The Challenges of Establishing World-Class Universities, Washington D.C.: WorldBank.

* Tyokyaa, C.I and Odeh, R.C (2017), Monograph on administration of tertiary institutions in Nigeria (EDM, 905).

* Viasceanu, L., Garunberg, L., Parica, D. (2007). Quality Assurance and Accreditation. A glossary of Basic Terms and Definitions, Bucharest: UNESCO-CEPS.0 